\title{
The effect of zeolite addition on parameters of concrete containing recycled ceramic aggregate
}

\author{
Jacek Szulej ${ }^{1,}{ }^{*}$, Pawet Ogrodnik ${ }^{2}$ \\ ${ }^{1}$ Lublin University of Technology, Faculty of Civil Engineering and Architecture, 40 Nadbystrzycka \\ Str., 20-618 Lublin, Poland \\ ${ }^{2}$ The Main School of Fire Service, Faculty of Fire Safety Engineering, 52/54 Słowackiego Str., 01- \\ 629 Warszawa, Poland
}

\begin{abstract}
In the paper it was decided to recognize the material characteristics of concrete based on ceramic aggregate, aluminous cement with the addition of zeolite $(5 \%, 10 \%, 15 \%)$ and air entraining admixture. Aggregate crushed to 2 fractions was used for designing the concrete mix : 0-4 $\mathrm{mm}$, and 4-8 $\mathrm{mm}$. The research involved the use of clinoptilolite derived from the zeolite tuff deposit at Sokyrnytsya (Transcarpathia, Ukraine). The dominant component in the zeolite is clinoptilolite in an amount of about $75 \%$. The research carried out by the authors showed that the addition of zeolite, among others, increases the compressive strength of concrete, significantly improves the frost resistance, which in the case of using only aluminous cement is very low. The obtained results confirm the possibility of using the above-mentioned components, which improve the concrete material properties and are environmentally friendly.
\end{abstract}

\section{Preliminary information on the properties and use of recycled ceramic aggregate and zeolite.}

Ceramic waste can be divided into two basic groups. The first group is waste from plants that produce products made of baked red clays (brick, ceramic blocks, and tile) [1]. The second group is production waste in plants manufacturing products based on white clays (sanitary ceramics, insulators, and table ceramics) [2, 3].

The research work carried out so far on the use of ceramics is currently focused mainly on the ecological effect. Research carried out by the authors of the work confirmed the possibility of using crushed ceramic elements as aggregates for concretes. However, due to the different characteristics of crushed red ceramics, the strength parameters differ significantly. The obtained results of compressive and tensile strength tests of such prepared concretes indicate an unfavorable relationship between the content of the red ceramic additive and the strength values. The strengths were the smaller, the higher was the content of the ceramic aggregate. Whereas, strength tests of concretes composed with aggregates made of sanitary and technical ceramic waste (sanitary ceramics, and ceramic electrical insulators) confirm the beneficial effect of this type of aggregate on the concrete

\footnotetext{
* Corresponding author: j.szulej@pollub.pl
} 
strength. Strength parameters of such concrete are similar, or even in the presented research, exceed concrete parameters made with traditional aggregates [4-9].

In the conducted studies [9], the authors describe the results of tests of the mechanical properties of concretes, in which thicker aggregate fractions $(5-20 \mathrm{~mm})$ were replaced with aggregates prepared from sanitary cullet. The compressive strengths of concretes obtained from mixtures prepared in this manner were tested after 14 days and 28 days after forming. The research shows that after 28 days the compressive strength was higher by $2-8 \%$ compared to the concrete with traditional aggregate, and grew with the content of ceramic aggregate. In the paper [8] was presented the results of concrete tests in which the powder obtained from ceramic cullet was replaced with part of the sand fraction. The ceramic powder was composed from 10 to $50 \%$ of the sand fraction. The research proved that the described additive had a beneficial effect on the concrete strength. Samples were tested after 14 days and 28 days after forming. The highest strength was obtained by concrete with the addition of ceramic powder in the amount of $50 \%$ of the sand fraction and it was greater by almost $20 \%$ compared to the concrete without the addition of powder. The authors of the works $[6,7]$ used white ceramic waste in the amount of $15-25 \%$ as an additive to the concrete aggregate. The test results obtained after 28 days showed a 2-11\% higher strength in relation to concrete made with gravel aggregate. The authors' own research [10], taking into account the specialist scope of using aggregate from sanitary cullet, where aluminous cement was also used, showed the reduction of the so-called spalling phenomenon occurring during the heating of concrete samples. At the same time, concrete containing aluminous cement and ceramic cullet aggregate showed little frost resistance. Considering this negative attribute, it was decided to examine the material properties of such concretes by adding zeolite as a cement supplement in the amount of 5 to $15 \%$ in relation to the cement mass.

Zeolites are a group of aluminosilicates with unique physicochemical properties, which give many practical benefits. These properties result mainly from their specific internal structure. In the spatial aluminosilicate skeleton there are free spaces in the form of chambers and channels with strictly defined molecular sizes. If we add high thermostability very good catalytic, sorption-ion-exchange and molecular-sieve properties to this chemical resistance, it is not surprising that zeolites are an extremely important material with numerous applications in chemical technologies, engineering and environmental protection, agriculture and construction [11-16]. Although in nature there are over 100 varieties of various types of zeolite minerals, the deposit accumulations form only a few of them. The most widely accepted zeolitic mineral as well as most commonly used is clinoptilolite. It crystallizes in a monoclinic system with a space group $\mathrm{C} 2 / \mathrm{m}$ and the parameters of the elementary cell: $a=1.766 \mathrm{~nm}, b=1.726 \mathrm{~nm}, c=0.720 \mathrm{~nm}, \beta=116.4^{\circ}$. The most frequently passed crystallographic formula of the clinoptilolite pattern is $\left(\mathrm{K}_{2}, \mathrm{Na}_{2}, \mathrm{Ca}\right) 3\left[\mathrm{Al}_{6} \mathrm{Si}_{30} \mathrm{O}_{72}\right] \cdot 24 \mathrm{H}_{2} \mathrm{O}$. Natural zeolites and especially clinoptilolite, when reacted with $\mathrm{Ca}(\mathrm{OH})_{2}$ are able to form typical gel hydration products $(\mathrm{C}-\mathrm{S}-\mathrm{H}, \mathrm{C}-\mathrm{A}-\mathrm{H})$. The content of $\mathrm{Ca}(\mathrm{OH})_{2}$ in hydration products decreases considerably, which is the cause of increased chemical resistance and lower porosity of systems with clinoplilolite cement. Therefore, this mineral is a natural valuable pozzolanic additive for the production of concrete. The diffractogram of the mineral composition of this rock is shown in Fig. 1. 


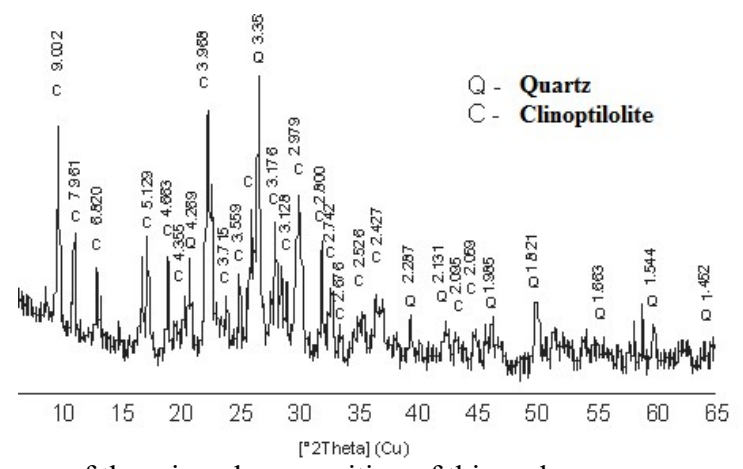

Fig. 1. The diffractogram of the mineral composition of this rock.

The results of concrete samples with the addition of zeolite are available in the literature [17-20] prove the significant efficiency of natural zeolite, which positively affects, among others, water penetration and concrete shrinkage, an increase of strength and durability, and resistance to corrosion.

\section{Description of tests}

The tests were carried out on a group of concrete samples, which included standard cubic samples for compressive strength and frost resistance tests. The concrete mix was based on the aluminous cement Górkal 70, recycled ceramic aggregate of 0-4 mm and 4-8 $\mathrm{mm}$ fractions and various zeolite supplements in the amount of $0 \%$ (base samples), 5\% (G5 samples), $10 \%$ (G10 samples) and 15\% (G15 samples) and a constant amount of air entraining admixture Microporan, which provides $10 \%$ aeration of the mixture. The samples contained constant amounts of aggregate and water, but they differed in the amount of cement and zeolite. The composition of the concrete mixture was already used in earlier studies by the authors, in the current study was added only zeolite. Formed samples were condensed on a vibrating table. After two days, samples binding was demoulded and for the whole maturation period they were placed in a water reservoir.

Detailed material data on the sample groups and division into series is presented in Table 1; the exact composition of mixtures corresponding to a volume of $1 \mathrm{~m}^{3}$ is presented below.

Table 1. List of material data regarding the prepared Samales.

\begin{tabular}{|c|c|c|c|c|}
\hline $\begin{array}{c}\text { Determination of a } \\
\text { series of samples }\end{array}$ & Base & G5 & G10 & G15 \\
\hline Cement & \multicolumn{4}{|c|}{ Górkal 70 } \\
\hline $\begin{array}{c}\text { The contribution of } \\
\text { zeolite (\% of cement } \\
\text { mass) }\end{array}$ & 0 & 5 & 10 & 15 \\
\hline $\begin{array}{c}\text { Coarse aggregate } \\
\text { Fine aggregate }\end{array}$ & \multicolumn{4}{|c|}{ recycled ceramic aggregate $4-8 \mathrm{~mm}$} \\
\hline Water & \multicolumn{3}{|c|}{ tap ceramic aggregate $0-4 \mathrm{~mm}$} \\
\hline
\end{tabular}


The exact composition of the four designed concrete mixtures used in the tests:

- Mixture G0: aluminous cement “Górkal 70" (488kg), aggregate 0-4mm (997,14kg), aggregate 4-8mm (398,86kg), water (199 1), air entraining admixture Mikroporan $(0,5 \mathrm{~kg})$,

- Mixture G5: aluminous cement “Górkal 70" (464kg), zeolite $(24 \mathrm{~kg})$, aggregate $0-4 \mathrm{~mm}$ $(997,14 \mathrm{~kg})$, aggregate $4-8 \mathrm{~mm}(398,86 \mathrm{~kg})$, water (199 1), air entraining admixture Mikroporan $(0,5 \mathrm{~kg})$,

- Mixture G10: aluminous cement “Górkal 70" (439kg), zeolite (49kg), aggregate 0-4mm $(997,14 \mathrm{~kg})$, aggregate $4-8 \mathrm{~mm}(398,86 \mathrm{~kg})$, water (199 1), air entraining admixture Mikroporan $(0,5 \mathrm{~kg})$,

- Mixture G15: aluminous cement "Górkal 70" (415kg), zeolite $(73 \mathrm{~kg})$, aggregate $0-4 \mathrm{~mm}$ $(997,14 \mathrm{~kg})$, aggregate $4-8 \mathrm{~mm}(398,86 \mathrm{~kg})$, water (199 1), air entraining admixture Mikroporan $(0,5 \mathrm{~kg})$,

The research was carried out in the Civil Engineering and Architecture Faculty of the Lublin University of Technology. The average compressive strength was determined after 7,14 and 28 days of maturation when each time there were examined three samples. The visual state of the samples was also determined during the freeze-thaw cycles in the chamber. There were cnducted a maximum of 150 freeze-thaw cycles until their surface damage was clearly visible. Each series contained six standard cubic samples.

\section{Test results of concrete samples regarding compressive strength and frost resistance}

Below, in the form of graphs, the obtained values of the material parameters of the concrete samples are summarized. Figure 2 shows the values of 7, 14 and 28 days compressive strength for four series of samples.

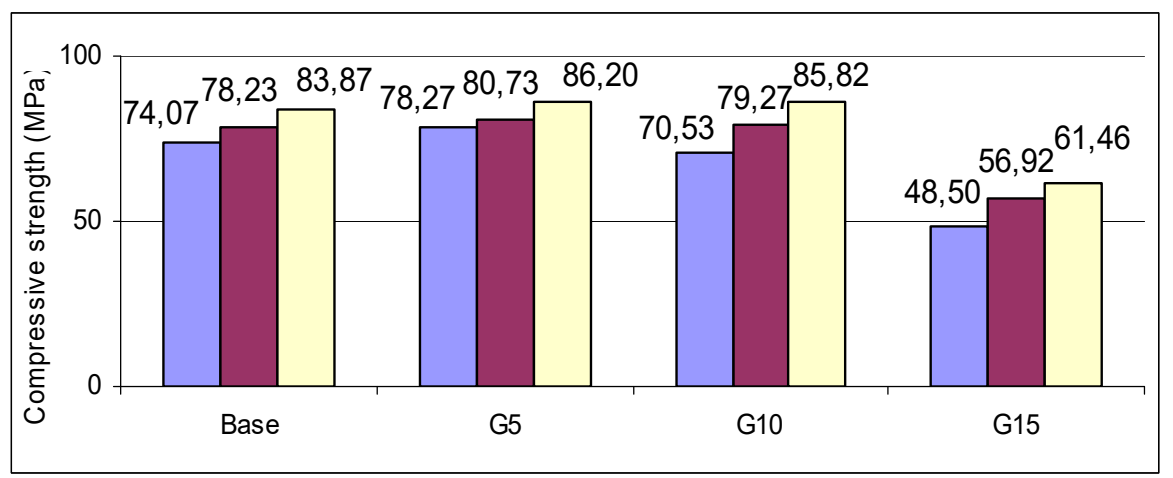

Fig. 2. The average compressive strength of four series of concrete samples.

The G5 series containing the 5\% zeolite supplement obtained the highest average compressive strength, the compressive strength of the G10 sample series developed at a comparable level. The lowest compression strength was obtained by the G15 series, resulting in a $28 \%$ decrease in strength with respect to the G5 group. Table 2 presents the results of frost resistance tests of concrete samples of four series. 
Table 2. The results of frost resistance tests of concrete samples of four series.

\begin{tabular}{|c|c|c|c|c|}
\hline \multirow{2}{*}{ Sample number } & \multicolumn{4}{|c|}{ Number of freezing cycles } \\
\cline { 2 - 5 } & Base & G5 & G10 & G15 \\
\hline 1 & 54 & 54 & 54 & 150 \\
\hline 2 & 42 & 54 & 54 & 150 \\
\hline 3 & 54 & 150 & 150 & 150 \\
\hline 4 & 47 & 130 & 47 & 150 \\
\hline 5 & 54 & 130 & 47 & 150 \\
\hline 6 & 47 & 54 & 54 & 150 \\
\hline Standard deviation & 5 & 46 & 40 & 0 \\
\hline $\begin{array}{c}\text { Average number of } \\
\text { freezing cycles }\end{array}$ & 50 & 95 & 68 & 150 \\
\hline
\end{tabular}

Considering the average number of freeze-thaw cycles of concrete samples the best result was obtained by the G15 samples containing $15 \%$ zeolite. Without visible damage, on the surfaces they were able to withstand 150 freeze cycles. Also, half of the samples of the G5 series showed resistance to at least 130 freeze cycles, reaching an average of 95 cycles. However, there were significant differences in the frost resistance values ranging from 54 to 150 cycles (the standard deviation was 46 cycles). In conclusion, the samples of the G15 series withstanding up to 150 freeze cycles showed a threefold increase in frost resistance in relation to the base samples not containing a zeolite supplement.

\section{Conclusions}

The results of the tests showed that the addition of zeolite has a positive effect on selected material properties of concrete containing aggregate from ceramic cullet, aluminous cement and zeolite supplement. A slight increase in compressive strength was observed for the series of G5 samples. Such a slight increase in compressive strength may be the effect of zeolite addition without taking into account the increased water demand of this mineral. Regarding the series of G15 samples, they showed a significant, threefold increase in frost resistance compared to the base samples, while obtaining the lowest compressive strength. The frost resistance results of the G5 and G10 sample series achieved a large standard deviation of 40-46 cycles. The obtained results present the preliminary stage of research on the use of zeolite in concretes containing ceramic aggregate and aluminous cement. It becomes relevant to conduct tests of the samples in high temperatures and to accurately identify the mechanisms that occur when combining these components.

\section{References}

1. W. Szolginia, Architektura. Warszawa: Sigma NOT (1992)

2. R. Pampuch, S. Błażewicz, G. Górny, Materiały ceramiczne dla elektroniki. Kraków: Wydawnictwa AGH (1993)

3. J. Antoniewicz, Własności dielektryków. Warszawa: Wydawnictwa Naukowo Techniczne (1991)

4. F. Pacheco-Torgal, S. Jalali, Constr Build Mater 24, pp. 832-838 (2010)

5. P. Awoyera, J. O. Akinmusuru, M. Ndambuki, Construction and Building Materials 117, pp.29-36 (2016) 
6. C. Medina, M.I. Sánchez de Rojas, C. Thomas, J.A. Polanco, M. Frías, Constr Build Mater 105, pp. 480-486 (2016)

7. C. Medina, M. Frías, M.I. Sánchez de Rojas, Constr Build Mater 31, pp. 112-118 (2012)

8. V. Lopez, B. Llamas, A. Juan, J.M. Moran, I. Guerra, Biosyst Eng, 96 (4), pp. 559-564 (2007)

9. I. Guerra, I. Vivar, B. Liamas, A. Juan, J. Moran, Waste management 29, pp. 643-646 (2009)

10. P. Ogrodnik, J. Szulej, Constr Build Mater 157, pp. 909-916 (2017)

11. M. Wdowin, M Franus, R. Panek, L. Bandura, W. Franus, Clean Technologies and Environmental Policy - DOI 10.1007/s10098-014-0719-6 (2014).

12. S. Chałupnik, W. Franus, M. Wysocka, G. Gzyl, Environmental Science and Pollution Research 20 pp. 7900-7906 (2013)

13. M. Wdowin, W. Franus, R. Panek, Fresenius Environmental Bulletin, 21 (12) pp. 3726 -3734 (2012)

14. W. Franus Polish Journal of Environmental Studies, 21 (2), pp. 337-343 (2012)

15. W. Franus, M. Wdowin, Mineral Resources Management, 26 (4) pp. 133 -148 (2010)

16. W. Franus, K. Dudek, Geologica Carpathica, 50 pp. 23-24 (1999)

17. M. Najimi, Construction and Building Materials 35, pp. 1023-1033 (2012)

18. B. Ahmadi, M. Shekarch. Cement \& Concrete Composites 32, pp.134-141 (2010)

19. J. Szulej, Budownictwo i Architektura 15 (4), pp. 109-116 (2016)

20. C. Bilim, Construction and Building Materials 25, pp. 3175-3180 (2011) 